question of ethnicity in the working class so central to American history; and finally the study of mass worker mobilizations, such as the revolutionary upsurge following World War I, on a truly international scale.

\author{
Bernard Moss \\ University of Southern California
}

\title{
ANGLO-AMERICAN LABOR HISTORY AT THE AHA
}

Of the three AHA sessions on working-class history we have been asked to report on, two were remarkably more successful than the third. One of those two, the session on "Working Class Political Culture" containing the especially important essay coauthored by Alan Dawley and Paul Faler, is discussed at length elsewhere.* Of the remaining two sessions, Paul and Thea Thompson's (Essex University, England) presentation of their oral history project on late Victorian and Edwardian England excelled. The panel on "Work and Industrial Discipline in Britain and America" did not.

David Montgomery (Pittsburgh) chaired the session on Work-Time-Discipline and ably attempted to focus the panel on the ways Edward Thompson, in his influential article "Time, Work, and Industrial Capitalism," has suggested industrial capitalism transformed pre-industrial work rhy thms. The panel would, then, try to view this process in three different settings: Puerto Rico in the Great Depression: changing time-schedules and work patterns of American women in recent United States' history; leisure activities in the late Victorian working class outside London. However, not only did these papers' analysis fall short of Thompson's rigorous theoretical example, but the extended presentations did not leave time for comparative discussion.

Montgomery summarized Thompson, tried to give a brief introduction to the other papers, and then discussed the methods adopted by American industrial workers to assert control over their working life. "Industrial time had created not spontaneous, universal obedience to the employers' values..." rather "the stint" and the eight-hour day reflected the workers' concent of a rational, modern distribution of work and time. While Montgomery provided an overview, the rest of the papers failed to address themselves successfully to the theoretical implications of work and timediscipline. Blanca Silvestrini (University of Puerto Rico) spoke on "Work Patterns of Puerto Rican Women in the Rural Industries." Silvestrini presented some interesting material on the family economy of Puerto Rican workers in the 1930s and women's efforts to unionize and assert a public presence in their community, but she neglected to connect her argument with the larger historical debate on the relationship among women's work, their public role, and their power within the family. Similurly, Joanne Vanek (Queens College) in her discussion of "Time Schedules and Work Patterns of Viarricd [American] Women," attacked the conventional assumption that labor-saving devices freed women to enter the workforce. The shift from women's paid labor inside the household (ie. piecework, hoarders), she argued, to paid labor outside the household was achieved at the cost of less :sce p. 13. 
leisure-time for women. The material was interesting, the topic important, but again the argument would have been strengthened had she examined structural changes in family life: no distinctions were drawn in regard to social class, age, ethnic and racial background, and, in particular, the changing historical character of women's life cycle as it relates to their diminishing years of child-rearing responsibilities. Finally, Joseph White (Pittsburgh), in his essay, "Work Experience of Textile Workers in England," tried to extend to English provincial working-class life Gareth Stedman Jones' description ("Working-Class Culture and Working-Class Politics in London, 1870-1900," Journal of Social History. Summer 1974) of a politically conservative but self-conscious London working class. He contrasted - and from the audience Martha Vicinus hotly contested - the aggressive, dynamic character of Lancashire soccer with the more "passive" music hall tradition. As Vicinus noted, however, the music hall was participatory: people sang along and shaped the character and history of the song. Furthermore, as current work by Stephan Yeo demonstrates, with professionalization, soccer underwent rapid transformation into a passive spectator activity.

In contrast to the above session, the session on Edwardian Oral History was a coherent presentation that held the attention of its sizeable audience. Paul Thompson discussed the methodological organization of their joint oral history project, while Thea Thompson presented a paper on Edwardian family life as an example of the interpretive synthesis that could be drawn from the interviews. Indeed, Paul Thompson distinguished their work from the largely archival efforts of most American oral history projects: rather they saw their interviews as a means of obtaining systematic evidence to illuminate various areas of the social history of Edwardian Britain. According to Paul Thompson, the interviews compensated for the dearth of sensitive Edwardian social investigations into the private lives and social perceptions of the poor comparable to the earlier works of Henry Mayhew and A. L. Munby.

In designing their research project, the Thompsons rejected random sampling in favor of a quota sampling of representative groups. They based their sample on occupational classifications, sex ratios. and regional and age distributions appropriate for the 1911 population. They then proceeded to fill up these caltegories with willing people. To find their informants, they used welfare workers and doctors: they placed letters in newspapers; they made use of personal contacts and personal encounars. a.. in the ase of one man they met on a park bench who was living under an alias. Thompson emphasized the need for interviewers who respected the informants; they often trained interviewers who shared age, regional, and class backgrounds with the people they were to interview. Lastly, the intervicwers had at their disposal a substantial list of questions which were to be used in a "flexible way" - as a means of prompting discussion as well as following up points of inquiry. Thea Thompson next suggested in an interpretive essay one way in which some of their material might be used.

According to Thea Thompson, dependency and separation were the determining features of Edwardian parent-child relationships. Various mechanisms were employed to main tain this distance among different classes. The well-to-do were most successful in maintaining separation through the use of nurscrics and domestic servants. In contrast, early bedtime and enforced silence at meals were the cffective agents of separation in servantless households. While these were the prevalent modes of childrearing, important variations were noticeable according to family size and date of marriage. In nadriages diter 1895 , the rule of silence was rare among middle-class families, where eating was vieweid 
as a social occasion. On the other hand, table manners were strictly enforced among working-class families and among families with large numbers of children.

The one exception to this style of socialization occurred among the Shetland Islanders. There none of the rigid time orientation generally characteristic of Edwardian childrearing was present. Cooperation and integration of work and leisure patterns were general features of community and family life. Children participated in evening, leisure-time activities with adults. Children and women worked in crafts and on the subsistence farms, while the men fished. The lack of rigid role division in work afforded both women and children respected roles in the family. As a consequence, Thompson argued, women were able to mitigate the more brutal aspects of the patriarchal, asymetrical family life visible in other parts of England. Finally, while Thea Thompson identified the economic role as the most important causal factor here, she acknowledged that religion, community organization, and long-standing cultural traditions may have contributed to the distinctive social life of the Shetland Islanders as well.

Unfortunately, under the confining limitations of such professional meetings, the Thompsons could only begin to describe the impressive scope and complexity of their project. Thea Thompson's presentation, however, offered insight into their work's tremendous potential value to historians of Edwardian Britain.

Judith R. Walkowitz, Rutgers University

Daniel J. Walkowitz, Rutgers University

\section{THE RUSSIAN MASSES IN THE OCTOBER REVOLUTION 1917}

(Participants - Chairman: Paul Avrich, Queens College, City University of New York: Petrograd Alexander Rabinowitch, Indiana University; The Provinces John Keep, University of Toronto; The Armies at the Front Allan Wildman, State University of New York, Stony Brook: Comment: Stephen Cohen, Princeton University.)

As the title indicates the central subject of this panel at the recent AHA meeting was to explore the role of three sectors of the Russian "masses" in the Bolshevik victory of October 1917. It should of course be noted that the readers limited their remarks to the Russian population and did not deal specifically with minority nationalities of the empire. Professors Rabinowitch and Wildman expressed the revisionist view that the Bolshevik program, if not their ideology was heartily supported by Russians in Petrograd and the army, while Professor Keep maintained the traditional Western position that identification with the Bolsheviks, at least among the Russian peasants in the countryside, was minimal.

Rabinowitch's paper developed the theme introduced in his monograph on the July Days, Prelude to Revolution which he is continuing in a forthcoming study. The Bolsheviks Come to Power. dealing with the revolution from July to October. Tracing the events of the summer and fall of 1917 , he sees the Bolshevik success due to the growing mass dissatisfaction with the reaction of the provisional government and other important political institutions in Russia. The Bolsheviks, in part because of their position outside of the government, could more readily appeal to this dissatisfaction than 